\title{
The Effects of Shopping Orientations, Online Trust and Prior Online Purchase Experience toward Customers' Online Purchase Intention
}

\author{
Kwek Choon Ling (Corresponding author) \\ Faculty of Management and Information Technology, UCSI University \\ 1, Jalan Menara Gading, UCSI Heights, 56000 Kuala Lumpur, Malaysia \\ Tel: 60-16-688-6248Ｅ-mail: kwekcl@ucsi.edu.my \\ Lau Teck Chai \\ Faculty of Accountancy and Management, Universiti Tunku Abdul Rahman
}

Lot PT21144, Jalan Sungai Long, Bandar Sungai Long, Cheras, 43000 Kajang, Selangor, Malaysia

Tel: 60-16-391-7683 E-mail: lautc@utar.edu.my

Tan Hoi Piew

Faculty of Accountancy and Management, Universiti Tunku Abdul Rahman

Lot PT21144, Jalan Sungai Long, Bandar Sungai Long, Cheras, 43000 Kajang, Selangor, Malaysia

Tel: 60-16-286-2719 E-mail: hptan@utar.edu.my

\begin{abstract}
The advancement of the World Wide Web has resulted in the creation of a new form of retail transactionselectronic retailing (e-tailing) or web-shopping. Thus, customers' involvements in online purchasing have become an important trend. As such, it is vital to identify the determinants of the customer online purchase intention. The aim of this research is to evaluate the impacts of shopping orientations, online trust and prior online purchase experience to the customer online purchase intention. A total of 242 undergraduate information technology students from a private university in Malaysia participated in this research. The findings revealed that impulse purchase intention, quality orientation, brand orientation, online trust and prior online purchase experience were positively related to the customer online purchase intention.
\end{abstract}

Keywords: Shopping orientations, Online purchase intention, Online trust, Prior online purchase experience.

\section{Introduction}

The advancement of the World Wide Web has resulted in the creation of a new form of retail transactionselectronic retailing (e-tailing) or web-shopping. The rapid growth of the Internet technology has enabled Malaysian consumers to purchase products or services from the web-retailers and search product information from the Internet. However, web-retailers can only offer certain ranges of products and services to web-shoppers, including e-banking services, technology gadgets, cosmetics, clothing and the booking of airlines ticket. Wolfinbarger and Gilly (2001) assert that web-shopping presents different shopping experiences even when the same products are purchased. Through web shopping, consumers interact in a virtual environment via the website interface (Alba, Lynch, Weitz and Janiszewski, 1997; Hoffman and Novak, 1996). Therefore, web shopping is perceived to be more risky and therefore trust and risk play prominent roles in online transaction (Forsythe and Shi, 2003; Pavlou, 2003). Web-shopping behaviour does not necessarily follow traditional consumer behaviour in the bricks-or-mortar retailing environment, thus Internet marketers are advised to explore the determinants of customer online purchasing intention among the web shoppers. With a good understanding of the web shopper's online purchase intention, web-retailers will be able to develop effective and efficient web-shopping strategies to attract new and potential web-shopping customers.

Some models for examining web-shopper behaviour such as technology acceptance models (TAM) (Davis, Bagozzi and Warshaw, 1989) and online pre-purchase intentions models (Shim, Eastlick, Lotz and Warrington, 2001) have appeared in the extant literature. Forsythe and Shi (2003) argue that web shopping is perceived to be more risky than brick-or-mortar retailing transaction. Since consumer behaviour is cultural-specific, it is unclear whether the reported findings of the consumer online purchase intention in the western countries (which exhibit low uncertainty avoidance in the Hofstede cultural typology) can be directly applied in a cross-cultural context such as in Malaysia (which exhibit high uncertainty avoidance in the Hofstede cultural typology), particularly among Generation Y. Consequently, a gap is created in this research. Therefore, this study aims to 
examine the impacts of shopping orientations, online trust and prior online purchase intention on the customer online purchase intentions in Malaysia, particularly among Generation Y.

\section{Literature Review}

\subsection{Internet Subscription in Malaysia}

Based on the research carried out by Maddox and Gong (2005), the Internet market penetration rate has increased dramatically in Asia region. According to the Malaysia Internet Usage and Telecommunication report (retrieved from http://www.internetworldstats.com/asia/my.htm), the number of Internet subscribers has increased from 2.9 million in year 2004 to close to 5 million in year 2006. Thus, there is a sight of positive growth in the Internet subscription and Internet purchase in Malaysia. Considering that web shopping is still at the development stage in Malaysia, not much information is known about consumer attitude toward web shopping and factors that affect customer online purchase intention in the web-shopping environment. Therefore, it is crucial to identify the determinants of consumer online purchase intention in the web-shopping environment in Malaysia context.

\subsection{Web-Shopping}

Advancement in the Internet technology has facilitated the growth of in-home shopping (Lumpkin \& Hawes, 1985). Shim, Quereshi and Siegel (2000) define web shopping as the process consumers go through to purchase products or services over the Internet. The terms online-shop, Internet-shop, web-shop and online-store are used interchangeably in the extant literature. Web shopping is an e-commerce system used by shoppers in the context of business-to-consumer (B2C) or business-to-business (B2B).

From the consumer's viewpoint, web shopping allows web shopper to search and compare various product or service alternatives from different online stores that are located in different parts of the world. The interactive nature of the Internet offers opportunities for consumers to use the web shopping facilities effectively by improving the availability of product information, enabling direct multi attributes comparison, and reducing prospective buyers' information search costs (Alba, et. al., 1997).

The Internet can also provide benefits to companies. As consumers are increasingly using the Internet as a shopping approach in performing their purchasing activities, companies can take this opportunity to use the Internet as a medium to attract and maintain current and potential customers. In this vein, online retailers must understand consumers' perceptions of website characteristics and their online shopping behaviour. Thus, the research will try to explore the concept of customer online purchase intention and the antecedent relationship of shopping orientations, online trust and prior online purchase experience on customer online purchase intention.

\subsection{Customer Online Purchase Intention}

Customer online purchase intention was one of the intensive research areas in the extant literature. Customer online purchase intention in the web-shopping environment will determine the strength of a consumer's intention to carry out a specified purchasing behaviour via the Internet (Salisbury, Pearson, Pearson and Miller, 2001). Furthermore, the theory of reasoned action suggested that consumer behaviour can be predicted from intentions that correspond directly in terms of action, target and context to that consumer behaviour (Ajzen and Fishbein, 1980). According to Day (1969), the intentional measures can be more effective than behavioural measures to capture customer's mind as customer may make purchases due to constraints instead of real preference when purchase is considered.

Purchase intention can be classified as one of the components of consumer cognitive behaviour on how an individual intends to buy a specific brand. Laroche, Kim and Zhou (1996) assert that variables such as consideration in buying a brand and expection to buy a brand can be used to measure consumer purchase intention. Based on the argument of Pavlou (2003), online purchase intention is the situation when a customer is willing and intends to become involved in online transaction. Online transactions can be considered as an activity in which the process of information retrieval, information transfer, and product purchase are taken place (Pavlou, 2003). The information retrieval and exchange steps are regarded as intentions to use a web site; however, product purchase is more applicable to an intention to handle a web-site (Pavlou, 2003). Therefore, it is crucial to evaluate the concept of online purchase intention in this study. In order to trigger customer online purchase intention, web retailers have to explore the impact of shopping orientations on the customer online purchase intention.

\subsection{Shopping Orientations}

Brown, Pope and Voges (2001) define shopping orientations as related to general predisposition toward the acts of shopping. This predisposition may be demonstrated in different forms such as information search, alternative 
evaluation, and product selection. Li, Kuo and Russell (1999) conceptualise the concept of shopping orientations as a specific portion of lifestyle and operationalised by a range of activities, interests and opinion statements that are relevant to the acts of shopping.

With the emergence of online shopping activities, customers' online shopping behaviour may be different in terms of their shopping orientations. Swaminathan, Lepkowska-White and Rao (1999) suggest that shopping orientations is one of the important indicators of making online purchase. Based on the relationship study between shopping orientations and online shopping orientation, Vijayasarathy and Jones (2000) identify seven types of shopping orientations, such as in-home shoppers who liked to shop from home; economic shoppers who shopped around before making purchase decisions; mall shoppers who preferred to shop at malls; personalized shoppers who liked to shop where they knew the salespeople; ethical shoppers who liked to shop in local stores to promote the community; convenience shoppers who placed a premium on convenience when shopping; and enthusiastic shoppers who enjoyed shopping. As the result of the study, it was found that customers who prefer traditional in-home shopping, such as by mail order via catalogs, tended to show high intentions toward online shopping, whereas individuals with a preference for mall shopping tended to have low online shopping intentions.

In the emergence of diverse retail outlets and increasing competition in the marketplace, online retailers must understand customers' shopping orientations in order to maximize customers' online purchase intention that leads to the increase in online sales. Several researchers have demonstrated that shopping orientations have significant impact on customer online purchase intention (Vijayasarathy \& Jones, 2000; Park, 2002; Brown, et. al., 2001; Seock, 2003; Gehrt, Onzo, Fujita and Rajan, 2007). Shopping orientations is regarded as a multi-dimensional construct. According to Gehrt, et. al. (2007), there are 7 types of shopping orientations which include recreation, novelty, impulse purchase, quality, brand, price, and convenience. However, the present research will only explore three types of shopping orientation that includes impulse purchase orientation, quality orientation, and brand orientation. Thus, impulse purchase orientation, quality orientation, and brand orientation will be grouped under the category of shopping orientations. This together with online trust and prior online purchase experience will be tested as the independent variables for customer online purchase intention.

\subsection{Impulse Purchase Orientation}

Piron (1991) defines impulse purchase as an unplanned action that result from a specific stimulus. Rook (1987) argues that impulse purchase takes place whenever customers experience a sudden urge to purchase something immediately, lack substantive additional evaluation, and act based on the urge. Several researchers have concluded that customers do not view impulse purchase as wrong; rather, customers retrospectively convey a favourable evaluation of their behaviour (Dittmar, Beattie, and Friese, 1996; Hausman, 2000; Rook, 1987). Therefore, Ko (1993) reports that impulse purchase behaviour is a reasonable unplanned behaviour when it is related to objective evaluation and emotional preferences in shopping.

Wolman (1973) frames impulsiveness as a psychological trait that result in response to a stimulus. Weinberg and Gottwald (1982) state that impulse purchase is generally emanated from purchase scenarios that feature higher emotional activation, less cognitive control, and largely reactive behaviour. Impulse purchasers also tend to be more emotional than non-purchasers. Consequently, some researchers have treated impulse purchase as an individual difference variable with the anticipation that it is likely to affect decision making across situations (Beatty and Ferrell, 1998; Rook and Fisher, 1995).

Given the ongoing development of the digital economy and the shopping convenience being delivered through digitalized exchanges, one might reason that more impulse individuals may be more prone to online shopping. Donthu and Garcia (1999) assert that online shoppers were more likely to be impulse oriented. The study from Zhang, Prybutok and Strutton (2007) conclude that impulse purchase is positively related to the customer online purchase intention.

\subsection{Quality Orientation}

Quality is regarded as a key strategic component of competitive advantage and therefore the enhancement of product or service quality has been a matter of main concern to firms (Daniel, Reitsperger, and Gregson, 1995; Foster and Sjoblom, 1996). Garvin (1987) identifies five approaches to define quality: transcendent, product-based, user-based, manufacturing-based, and value-based. Transcendent definition of quality is synonymous with innate excellence. The assumption of transcendent approach is that quality is both absolute and universally recognizable. The product-based approach has its roots in economics. Garvin (1984) argues that differences in the quantity of some ingredients or attributes possessed by the product are considered to reflect differences in quality. Whereas in the user-based definition, quality is the extent to which a product or service 
meets or exceeds customers' expectations. The manufacturing-based approach has its roots in operation and production management. Its quality is defined as conformance to specifications (Crosby, 1979). Quality of conformance relates to the degree to which a product meets certain design standards. Besides, the value-based definition equates quality with performance at an acceptable price, or alternatively conformance at an acceptable cost.

The impact of quality orientation on online purchase intention is well documented in the extant literature. Bellenger and Korgaonkar (1980) state that recreational shoppers tended to consider quality, variety of product types and pleasant store atmosphere as important factors when choosing stores. In the context of web-shopping environment, Gehrt, et al. (2007) discovered that customers from the shopping enjoyment segment are positively inclined toward recreation, quality, and impulse orientations when making online purchase.

\subsection{Brand Orientation}

A brand is defined as a name or symbol, trademark and package design that uniquely identifies the products or services of a retailer, and differentiates them from those of its competitors (Aaker, 1991). In the cyber marketplace, a corporate brand identity is a cognitive anchor and a point of recognition where customers perceive a great deal of uncertainty (Rajshekhar, Radulovich, Pendleton and Scherer, 2005). For many online retailers, the brand name is the company name. In the e-commerce environment, trusted corporate and brand names are used by customers as substitutes for product information when they intent to make online purchase (Ward and Lee, 2000).

Several studies have found that brand loyalty exhibits strong impact on purchase intention in the traditional offline retailing world (Hawes and Lumpkin, 1984; Sproles and Kendall, 1986). A strong brand name not only attracts new customers, but also has the lock-in ability to make customers feel comfortable with their purchase decisions. A study carried out by Jayawardhena, Wright and Dennis (2007) conclude that brand orientation is positively related to the customer online purchase intention.

\subsection{Online Trust}

According to Kramer (1999), trust is a complex statement because individuals do not know what the motives and intentions of others are. Kimery and McCard (2002) define trust as customers' willingness to accept weakness in an online transaction based on their positive expectations regarding future online store behaviour. According to Barber (1983), trust is an expectation about individuals' behaviour within the society where they are living or by which they are ruled. Trust can be bestowed upon a person, an object (product), an organization (a business), an institution (the government) or a role (a professional of some kind).

Trust plays a key role in creating satisfied and expected outcomes in online transaction (Pavlou, 2003; Yousafzai, Pallister, and Foxall, 2003; Gefen and Straub, 2004; Wu and Cheng, 2005; Flavian and Guinaliu, 2006). According to the McCole and Palmer (2001), online purchasing necessitates online customer trust. Egger (2006) argues that sufficient trust needs to exist when placing an order online and when the customer submit his or her financial information and other personal data in undertaking financial transactions. Gefen (2000) asserts that the present of trust will increase the consumers' belief that the e-retailers will not engage in opportunistic behaviour. It has been demonstrated in the extant literature that trust beliefs positively influence customer online purchase intention (Verhagen, Meents, and Tan, 2006; Verhagen, Tan and Meents, 2004; McKnight, Choudhury and Kacmar, 2002; Lim, Sia, Lee and Benbasat, 2001; Jarvenpaa, Tractinsky, and Vitale, 1999). Jarvenpaa and Tractinsky (1999) and Gefen and Straub (2004) conclude that the higher the degrees of consumers' trust, the higher degree of consumers' purchase intentions of consumers.

Dimensions of online trust include security, privacy and reliability (Camp, 2001). Security is defined as the extent to which customers trust that the Internet is secure for them to transmit sensitive information to the business transaction (Kim and Shim, 2002). Security plays a crucial role in affecting the consumer attitudes and purchase intentions (Salisbury, et. al., 2001) because the present of perceived risk in transmitting sensitive information such as credit card numbers across the Internet (Janda, Trocchia, and Gwinner, 2002). Ernst and Young (cited in Lee and Turban, 2001) suggests that consumers may feel uncomfortable to release their personal information such as credit card and social security number through Internet because the consumers cannot physically check the quality of the products or monitor the safety and security of sending sensitive personal and financial information while shopping on the internet. Kim and Shim (2002) emphasize that the personal awareness of security has the significant influence on consumer attitudes and online purchase intentions.

Chen and Barnes (2007) define privacy as the consumers' trust about the performance of other party in the environment during the market transaction or consumption behaviour. Lee and Turban (2001) argue that high 
level of security and privacy in the online shopping experience has a positive effect on consumer trust due to the perceived risk involved in the information exchange. Moreover, company reliability can influence the consumers' online trust and purchase intention (Balasubramanian, Konana, and Menon, 2003; Koufaris and Hampton-Sosa, 2004). In the web-shopping environment, most consumers assume that the large companies have better ability to increase their online trust (Koufaris and Hampton-Sosa, 2004). It is also proposed that a company with positive reputation does increase the consumers' trust (Doney and Cannon, 1997; Figueiredo, 2000).

\subsection{Prior Online Purchase Experience}

Helson (1964) argued that an individual's response to a judgmental task is based on three aspects, which are sum of the individual's past experiences, context or background, and stimulus. Web shopping is a relatively new activity for a wide range of consumers, online purchases are still perceived as riskier than terrestrial ones (Laroche, Yang, McDougall and Bergeron, 2005). Therefore, web-shopping consumers will depend heavily on experience quality in which the experience quality can be obtained only through prior purchase experience.

Prior experiences will strongly affect future behaviour. In the web-shopping context, customers evaluate their online purchase experiences in terms of perceptions regarding product information, form of payment, delivery terms, service offered, risk involved, privacy, security, personalization, visual appeal, navigation, entertainment and enjoyment (Burke, 2002; Parasuraman and Zinkhan, 2002; Mathwick, Malhotra, and Rigdon, 2001).

According to Elliot and Fowell (2000), customer experience with the Internet drives the growth of Internet shopping. Shim and Drake (1990) argue that customers with strong online purchase intention in web shopping usually have prior purchase experiences that assist in reducing their uncertainties. Therefore, customers will only purchase product from the Internet after they have already experienced them. In additional, customers who have prior online purchase experience will be more likely to purchase through online than those who lack such experience. Seckler (2000) explains this phenomenon that as individual gain experience with web-shopping, perhaps with small purchases at first, they will be more likely to develop confidence and skills that facilitate more ambitious buying through the Internet.

Dabholkar (1994) asserts that when an individual has less prior knowledge of the problems encountered, behavioural choice is mostly depended on expectancy-value model. Therefore, shoppers who have never done an online purchase before are more risk-averse than who have bought products through online means (Lee and Tan, 2003). If prior online purchase experiences resulted in satisfactory outcomes, this will lead customers to continue to shop on the Internet in the future (Shim, et. al., 2001). Unfortunately, if these past experiences are evaluated negatively, customers will be reluctant to engage in online shopping in the future. This explains the importance of turning existing Internet shoppers into repeat shoppers by providing them with satisfying online shopping experiences (Weber and Roehl, 1999).

Based on the vast extant literature, it can be concluded that customer's online purchase experience will have a significant effect on his or her future purchase intention for online shopping (Shim et al., 2001; So et al., 2005; Brown, et. al., 2001; Lynch and Ariely, 2000).

\subsection{Hypotheses}

Prior discussion has led to a brief examination of the existing literature and the development of the hypotheses in this research. The five hypotheses are:

H1: Impulse purchase orientation is positively related to customer online purchase intention.

H2: Quality orientation is positively related to customer online purchase intention.

H3: Brand orientation is positively related to customer online purchase intention.

H4: Online trust is positively related to the customer online purchase intention.

H5: Prior online purchase experience is positively related to customer online purchase intention.

\section{Methodology}

\subsection{Research Design}

Positivism approach was adopted in this research because this method allowed the researcher to search for truths of the observation by empirical evidence via the hypothetico-deductive method (Jankowicz, 2005). Furthermore, descriptive research design was adopted as the study has clear problem statements, specific hypotheses and detailed body of knowledge (Malhotra, 2004). 


\subsection{Questionnaire Design}

The first part (Part A) of the questionnaire provides general information about the online purchasing behaviour of the potential respondents. The second part of the questionnaire elaborates the independent variables and dependent variable that would be tested in the survey. Questions in the form of scaled-response questions were adopted in the second part of the questionnaire because "scaling permits measurement of the intensity of respondents' answers" (Churchill and Brown, 2004, p.329). The third part of the questionnaire identifies demographic profile of the respondents.

The items of the questionnaire in this research were adopted from different sources of the extant literature.

The items for the independent variables "impulse purchase orientation", "quality orientation", and "brand orientation" are adapted from Gehrt, et. al. (2007) and Seock (2003). The items for the independent variable "online trust" are adapted from Chen and Barnes (2007). The items for the independent variable "prior online purchase intention" are adapted from Brunelle and Lapierre (2008). The items for the dependent variable "online purchase intention" are adapted from Chen and Barnes (2007). A 5-point Likert scale anchored by "strongly disagree" (1) to "strongly agree" (5) was used as the attitude measurement for the independent and dependent variables.

\subsection{Sampling}

Solomon, Dann, Dann and Russell-Bennett (2007, p.477) define Generation Y as "kids born between 1979 and 1994 (the younger siblings of Gen Xers)". Since the study focused on Generation Y, the target population covered all the undergraduate students enrolled in University ' $A$ ' and the sampling unit included all the current full-time undergraduate information technology students in University 'A'. All of these undergraduate students are born between 1986 and 1990. The university is one of the largest private universities in Malaysia; with an estimated student population of 18,000 pursuing 84 programs in nine faculties spread over four campuses. Students who had actual online purchase experience were targeted. The respondents were selected through the filtering question in the questionnaire. The targeted sample size was 250 and convenience-sampling technique was used to select potential respondents in this survey. Convenience sampling technique was adopted because the research looks for cross-cultural differences in consumer behaviour (ie., customer online purchase intention) (Zikmund, Babin, Carr and Griffin, 2010) and "convenience samples are best used for exploratory research when additional research will subsequently be conducted with a probability sample" (Zikmund, et al., 2010, p.396; Sekaran and Bougie, 2010). Respondents were instructed to answer the questions based on their most recent online purchase experience with one of the web-retailer via the Internet.

\subsection{Administration of Survey}

Self-administered survey method in the form of drop-off surveys technique was used to ensure the confidentiality and non-obligation aspects of participating in the survey. The survey was conducted in the lecture hall where respondents could return the questionnaires immediately into the box allocated. The voluntary nature of the participation was explained verbally as well as being indicated in the survey questionnaire. Students were invited to complete an anonymous survey questionnaire that took approximately 15 minutes of their time to complete.

A total of 250 sets of questionnaires were distributed and 248 questionnaires were collected. Out of that, 8 sets of questionnaires were considered unusable because they were incomplete. It was assumed that the respondents were either unwilling to cooperate or not serious with the survey. Therefore, subsequently only 242 usable questionnaires (96.8 percent) were used for data analysis using SPSS software version 14.

\section{Research Results}

\subsection{Respondents' Demographic Profile and Online Purchasing Behaviour}

Based on the survey, male respondents represented 52.07 percent of the total respondents while female respondents 47.93 percent. In the case of age distribution, the majority of the respondents were between the ages of 21 to 23 (76.86 percent). In terms of ethnic compositions, the respondents were mainly Chinese ethnic group (91.74 percent). In the category of current year of study, most of the respondents study in year $3(62.81 \%)$. Based on the survey, all the respondents $(100 \%)$ have the experience of purchasing products and services via the online mode. Movie tickets (33.34\%) and technology gadgets $(21.43 \%)$ were the two most common items purchased by the respondents. At least half of the respondents (53.72\%) use credit card as a mode of payment in the online purchasing process.

\subsection{Reliability Test}

The reliability of a measure indicates the stability and consistency with which the instrument measures the concept and helps to assess the 'goodness' of a measure (Cavana, Delahaye and Sekaran, 2001). All the 
constructs were tested for the consistency reliability of the items within the constructs by using the Cronbach Alpha reliability analysis. In Table 1 , the results indicated that the Cronbach alpha for all the constructs were well above 0.7 as recommended by Cavana, et. al. (2001). Cronbach alpha for the constructs ranged from the lowest of 0.797 (prior online purchase experience) to 0.880 (online trust). In conclusion, the results showed that the scores of the Cronbach alpha for all the constructs used in this research exceeded the preferable scores of 0.70 and this indicated that the measurement scales of the constructs were stable and consistent.

\subsection{Validity Test}

Construct validity was adopted as validity measurement and factor analysis was used to measure the construct validity (Cavana, et. al., 2001). The details of the factor analysis were presented in Table 1 . Based on the output shown, factor analysis was appropriate because the value of Kaiser-Meyer-Olkin (KMO) was 0.867 (between 0.5 and 1.0) and the statistical test for Bartlett test of sphericity was significant $(\mathrm{p}=0.000$; d.f. $=325)$ for all the correlations within a correlation matrix (at least for some of the constructs). Based on the principal components analysis and VARIMAX procedure in orthogonal rotation, the results also showed that the Eigenvalues for all the constructs were greater than 1.0, ranging from the lowest 8.210 (online purchase intention) to the highest of 18.131 (online trust). In terms of convergent validity, the factor loadings for all items within a construct were more than 0.50 . Discriminant validity indicated that all items were allocated according to the different constructs. Therefore, the items were not overlapping and they supported the respective constructs.

\subsection{Regression Analyses}

\subsubsection{Multiple Regression Analysis}

Before employing regression analysis, there are six assumptions to be addressed. The assumptions include: (1) normality; (2) linearity; (3) independence of error term; (4) free from multicollinearity; (5) free from heterocedasticity; and (6) free from outlier and influential observations (Field, 2005). Based on the normally distributed histogram that was generated from the SPSS analysis, the normality assumption was met because the distribution of the residuals appeared to be unimodal and symmetric. From the scatterplot diagram, both the conditions of linearity and free from heterocedasticity were met because the residuals appeared to be randomly scattered and showed no patterns or clumps when plotted against the predicted values. The independence of error term was also met because the value of Durbin-Watson was 1.886, which was close to 2 (the closer to the value to 2, the better the independence of error) (Field, 2005, p.189). From the multicollinearity statistics generated, VIF values were all well below 10 and the tolerance statistics were all well above 0.2 ; therefore the data was free from multicollinearity. Lastly, the normal p-p plot analysis indicated that the data was free from outlier and influential observations because the normal probability plot was seen to be a straight line and the spread of the residuals were uniformed when plotted against the predicted values.

The result of the multiple regression analysis was presented in Table 2. The $p$ value of the impulse purchase orientation $(\mathrm{p}=0.000)$ is less than the alpha value of 0.05 . Therefore, the research concludes that an impulse purchase orientation is positively related to the customer online purchase intention. Hypothesis 1 is supported. This finding supports the existing literature which states that the shopping orientations in term of impulse purchase will positively affect the online purchase intention (Zhang, et. al., 2007).

The $p$ value for the quality orientation $(p=0.034)$ is also less than the alpha value of 0.05 . Therefore, it can be suggested that quality orientation is positively related to the customer online purchase intention. Hypothesis 2 is therefore supported. This finding supports the existing literature that quality orientations will positively influence the customer online purchase intention (Gehrt, et. al., 2007).

The result from the research also postulated that the brand orientation is positively related to the customer online purchase intention, as the alpha value is less than 0.05 ( $\mathrm{p}$ value $=0.001$ ). Hypothesis 3 is therefore supported. According to Jayawardhera, et. al. (2007), brand orientation is positively related to the customer online purchase intention.

Hypothesis 4 is supported in this research. The $p$ value of the online trust $(p=0.000)$ is less than the alpha value of 0.05 . Therefore the hypothesis that indicates the positive relationship between online trust and the customer online purchase intention is supported. According to McCole and Palmer (2001), online purchasing necessitates online trust.

Finally, the result from the research also indicated that the prior online purchase experience is positively related to the customer online purchase intention, as the alpha value is less than 0.05 ( $\mathrm{p}$ value $=0.000$ ). Hypothesis 5 is therefore supported. According to Shim and Drake (1990), customers with strong online purchase intention in web-shopping usually have prior purchase experiences that assist in reducing their uncertainties. 
Based on the SPSS output, the following multiple regression equation was formed:

Customer Online Purchase Intention $=-0.546+0.170$ (Impulse Purchase Orientation) +0.100 (Quality Orientation) +0.130 (Brand Orientation) +0.091 (Online Trust) +0.279 (Prior Online Purchase Experience)

The values of the un-standardized Beta coefficient among the independent variables ranges from the weakest relationship of 0.091 (online trust) to the strongest relationship of 0.279 (prior online purchase experience). Therefore, "prior online purchase experience" is the most important antecedent in affecting the customer online purchase intention. "Impulse purchase orientation" (0.170), "brand orientation" (0.130), and "quality orientation" $(0.100)$ are ranked second, third and fourth most important antecedents affecting the customer online purchase intention. In addition, the customer online purchase intention is explained 48.2 percent by the combination of the five independent variables $(r$ square $=0.694)$, which includes impulse purchase orientation, quality orientation, brand orientation, online trust and prior online purchase experience. Table 3 shows the summary of the five hypotheses and its outcomes.

\section{Conclusion}

\subsection{Implications of the Research}

The research findings have brought managerial implications to the various stakeholders. In terms of managerial implication, the research findings do provide some insights and feedbacks for the e-retailers to formulate and implement various business strategies to increase the customer online purchase intention. The research finding discovered that the antecedents of the customer online purchase intention could be applied in both low uncertainty avoidance countries and high uncertainty avoidance countries (especially in Malaysia), particularly among Generation Y. To create the condition for prior online purchasing experience, e-retailers can provide free samples or free subscription for the potential web shoppers to test the products or services. To increase the customer impulse purchase, e-retailers can provide e-mail updates on product development or offer special discounts for a limited time to the potential online customers. E-retailers may offer loyalty programmes or club memberships for those online customers who exhibit strong brand orientation. For targeting quality-orientated customers, e-retailers can provide full online version of product quality information and product search information through the website to them. To increase the level of online trust, e-retailers must provide honest and trustworthy information to the potential web shoppers at all time.

\subsection{Limitations of the Research}

Although the research findings provide some new insights to researchers, these findings should be viewed in light of some limitations. The study in this research is focusing on those respondents who have some experiences in engaging online purchase intention. Therefore, the study does not cover those potential customers who do not have experienced in online transaction but have the intention to engage in online purchase activities. By incorporating the potential online customers in the study, this will enhance the generalisability of the subsequent research. In addition, the study does not explore the impact of gender differences in moderating the relationship between shopping orientations and customer online purchase intention. The finding from Jayawardhena, et. al. (2007) discovered that gender has a significant influence on online purchase intention. By incorporating the gender construct in studying the relationship between shopping orientations, and customer online purchase intention may able to enrich the extant literature. Lastly, the adoption of convenience sampling technique may limit how well the research represents the intended population (Zikmund, et al., 2010, p.396). Consequently, the respondents may not be representative and the study not generalisable.

\subsection{Recommendations for Further Research}

Due to the limitations of this research, three recommendations are suggested for further research for the purpose of enhancing the study of the customer online purchase intention. It is proposed to evaluate the impacts of shopping orientations, online trust and prior online purchase experience on the customer online purchase intention among the potential customers who have strong intention to engage in online purchasing activities. Besides, it is recommended to evaluate the relationship between shopping orientations and customer online purchase intention based on gender differences as well as the role of gender in mediating the relationship between shopping orientations and customer online purchase intention. Lastly, it is suggested to utilize probability sampling technique to evaluate customer online purchase intention in the future research.

\section{References}

Aaker, D.A. (1991). Managing brand equity: Capitalizing on the value of brand name, New York: Free Press. 
Ajzen, I. and Fishbein, M. (1980). Understanding attitudes and predicting social behavior, New Jersey: Prentice-Hall.

Alba, J., Lynch, J., Weitz, B. and Janiszewski, C. (1997). 'Interactive home shopping: consumer, retailer, and manufacturer incentives to participate in electronic marketplaces', Journal of Marketing, 61(3), 38-53.

Balasubramanian, S., Konana, P. and Menon, N. (2003). 'Customer satisfaction in virtue environment: A study of online investing', Management Service, 49(7), 871-889.

Barber, B. (1983). The Logic and Limits of Trust, New Brunswick: Rutgers University Press.

Beatty, S.E. and Ferrell, M.E. (1998). 'Impulse buying: modeling its precursors', Journal of Retailing, 74(2), 169-191.

Bellenger, D.N., and Korgaonkar, P.K. (1980). 'Profiling the recreational shopper', Journal of Retailing, 56(3), $77-92$.

Brown, M., Pope, N. and Voges, K. (2001). 'Buying or browsing? An exploration of shopping orientations and online purchase intention', European Journal of Marketing, 37(11), 1666-1684.

Brunelle, E. and Lapierre, J. (2008). 'Testing media richness theory to explain consumers' intentions of buying online', Proceedings of the 10th International Conference on Electronic Commerce. ACM International Conference Proceedings Series, 342.

Burke, R.R. (2002). 'Technology and the customer interface: What consumers want in the physical and virtual store?' Journal of the Academy of Marketing Science, 30(4), 411-432.

Camp, L.J. (2001). 'Trust and risk in Internet Commerce', Cambridge, M.A.: MIT Press.

Cassill, N.L., Thomas, J.B. and Bailey, E.M. (1997). 'Consumers' definitions of apparel value: an investigation of department store shoppers', Journal of Fashion Marketing Management, 1(4), 308-321.

Cavana, R.Y., Delahaye, B. L., and Sekaran, U. (2001). Applied business research: Qualitative and quantitative methods, Queensland: John Wiley \& Sons.

Chen, Yu-Hui and Barnes, S. (2007). 'Initial trust and online buyer behavior', Industrial Management \& Data Systems, 107(1), 21-36.

Churchill, G.A. and Brown, T.J. (2004). Basic marketing research, $5^{\text {th }}$ edn, Ohio: South-Western.

Crosby, P.B. (1979). Quality is free: The art of making quality certain, New York: New American Library.

Dabholkar, P. (1994). 'Incorporating choice into an attitudinal framework: analyzing models of mental comparison processes', Journal of Consumer Research, 21(1), 100-118.

Daniel, S.J., Reitsperger, W.D. and Gregson, T. (1995). 'Quality consciousness in Japanese and U.S. electronics manufacturers: An examination of the impact of quality strategy and management control systems on perceptions of the importance of quality to expected management rewards', Management Accounting Research, 6(4), 367-382.

Davis, F.D., Bagozzi, R.P. and Warshaw, P.R. (1989). 'User acceptance of computer technology: A comparison of two theoretical models', Management Science, 35(8), 982-1003.

Day, G. (1969) ‘A two dimensional concept of brand loyalty’, Journal of Advertising Research, 9(3), 29-35.

Dittmar, H., Beattie, J. and Friese, S. (1996). 'Object, decision and considerations and self image in men's and women's impulse purchases’, International Journal of Psychonomics, 93(1-3), 187-206.

Doney, P.M. and Cannon, J.P. (1997). 'An examination of the nature of trust in buyer-seller relationships', Journal of Marketing, 61(2), 35-51.

Donthu, N. and Garcia, A. (1999). 'The internet shopper', Journal of Advertising Research, 39(3), 52-58.

Egger, A. (2006). 'Intangibility and perceived risk in online environments', Academy of Marketing, London: University of Middlesex.

Elliot, S. and Fowell, S. (2000). 'Expectations versus reality: A snapshot of consumer experiences with internet retailing', International Journal of Information Management, 20(5), 323-336.

Figueiredo, J.M. (2000). 'Finding sustainability in electronic commerce', Sloan Management Review, 41(4), 41-51.

Field, A. (2005). Discovering statistics using SPSS, $2^{\text {nd }}$ edn. London: SAGE Publications Ltd. 
Flavian, C. And Guinaliu, M. (2006). 'Consumer trust, perceived security and privacy policy: Three basic elements of loyalty to a web site', Industrial Management \& Data Systems, 106(5), 601-620.

Forsythe, S.M. and Shi, B. (2003). 'Consumer patronage and risk perceptions in internet shopping', Journal of Business Research, 56(11), 867-875.

Foster, G. and Sjoblom, L. (1996). 'Quality improvement drivers in the electronic industry', Journal of Management Accounting Research, 8, 55-86.

Garvin, D.A. (1984). 'What does product quality really mean?', Sloan Management Review, Fall, 25-43.

Garvin, D.A. (1987). 'Competing on the eight dimensions of quality', Harvard Business Review, 65(6), 101-109.

Gefen, D. (2000). 'E-commerce: The role of familiarity and trust', OMEGA The International Journal of Management Science, 28(6), 725-737.

Gefen, D. And Straub, D.W. (2004). 'Consumer trust in B2C e-commerce and the importance of social presence: Experiments in e-products and e-services', Omega, 32(1), 407-424.

Gehrt, K.C., Onzo, N., Fujita, K. and Rajan, N.R. (2007). 'The emergence of internet shopping in Japan: identification of shopping orientation-defined segment', Journal of Marketing Theory and Practice, 15(2), 167-177.

Hausman, A. (2000). 'A multi-method investigation of consumer motivations in impulse buying behavior', Journal of consumer marketing, 17(15), 403-419.

Hawes, J.M. and Lumpkin, J.R. (1984). 'Understanding the shopper', Journal of the Academy of Marketing Science, 12(4), 200-218.

Helson, H. (1964). Adaptation-level theory, New York: Harper \& Row.

Hoffman, D.L. and Novak, T.P. (1996). 'Marketing in hypermedia computer-mediated environments: conceptual foundations', Journal of Marketing, 60(3), 50-68.

Howell, R. D. (1979). A multivariate examination of a patronage model: The impact of values and life styles on shopping orientations. Unpublished doctoral dissertation, University of Arkansas, Fayetteville.

Janda, S., Trocchia, P.J. and Gwinner, K.P. (2002). 'Consumer perceptions of internet retail service quality', International Journal of Service Industry Management, 13(5), 412-431.

Jankowicz, A.D. (2005). Business research project, $4^{\text {th }}$ edn. London: Thomson Learning.

Jarvenppa, S.L. and Tractinsky, N. (1999). 'Consumer trust in an Internet store: A cross-cultural validation', Journal of Computer-Mediated Communications, 5(2).

Jarvenppa, S.L., Tractinsky, N. and Vitale, M. (1999). 'Consumer trust in an internet store', Information Technology and Management, 1(12), 45-71.

Jayawardhena, C., Wright, L.T. and Dennis, C. (2007). 'Consumer online: Intentions, orientations and segmentation', International Journal of Retail \& Distribution Management, 35(6), 515-526.

Kim, Y.M. and Shim, K.Y. (2002). 'The influence of internet shopping mall characteristics and user traits on purchase intent', Irish Marketing Review, 15(2), 25-34.

Kimery, K.M. and McCard, M. (2002). 'Third-party assurances: Mapping the road to trust in e-retailing', Journal of Information Technology Theory and Application, 4(2), 63-82.

Ko, S. (1993). The study of impulse buying of clothing product. Unpublished Master's thesis, Seoul National University, Seoul.

Koufaris, M. and Hampton-Sosa, W. (2004). 'The development of initial trust in an online company by new customers', Information \& Management, 41(3), 377-397.

Kramer, R.M. (1999). 'Trust and distrust in organizations: Emerging perspectives, enduring questions', Annual Review of Psychology, 50, 569-598.

Laroche, M., Kim, C. and Zhou, L. (1996). 'Brand familiarity and confidence as determinants of purchase intention: an empirical test in a multiple brand context', Journal of Business Research, 37(2), 115-120.

Laroche, M., Yang, Z., McDougall, G.H.G. and Bergeron, J. (2005). 'Internet versus bricks- and mortar retailers: An investigation into intangibility and its consequences', Journal of Retailing, 81(4), 251-267. 
Lee, K.S. and Tan, S.J. (2003). 'E-retailing versus physical retailing: A theoretical model and empirical test of consumer choice', Journal of Business Research, 56(11), 877-885.

Lee, M.K.O. and Turban, E. (2001). 'A trust model for consumer internet shopping', International Journal of Electronic Commerce, 49(1), 75-91.

Li, H., Kuo, C. and Russel, M.G. (1999). 'The impact of perceived channel utilities, shopping orientations, and demographics on the consumer's online buying behavior', in Steinfield, C.W., New Directions in Research on E-Commerce. Purdue University Press: Indiana.

Lim, K.H., Sia, C.L., Lee, M.K.O. and Benbasat, I. (2001). 'How do I trust you online and, if so, will I buy? An empirical study on designing web contents to develop online trust', The University of British Columbia, Vancouver.

Lumpkin, J. R., \& Hawes, J. M. (1985). 'Retailing without stores: An examination of catalog shoppers', Journal of Business Research, 13(2, April), 139-151.

Lynch, J.G.Jr. and Ariely, D. (2000). 'Wine online: Search costs affect competition on price, quality, and distribution', Marketing Science, 19(1), 83-103.

Maddox, L.M. and Gong, W. (2005). 'Effects of URLs in traditional media advertising in China', International Marketing Review, 22(6), 673-692.

Malaysia Internet Usage and Telecommuication Report. Retrieved April 4, 2010, from http://www.internetworldstats.com/asia/my.htm

Malhotra, N.K. (2004). Marketing research: An applied orientation, $4^{\text {th }}$ edn, New Jersey: Prenticall-Hall.

Mathwick, C., Malhotra, N. and Rigdom, E. (2001). 'Experiential value: Conceptualization, measurement and application in the catalog and Internet shopping environment', Journal of Retailing, 77(1), 39-56.

McCole, P. and Palmer, A. (2001). 'A critical evaluation of the role of trust in direct marketing over the internet', World Marketing Congress, University of Cardiff, Wales.

McKnight, D.H., Choudhury, V. and Kacmar, C. (2002). 'Developing and validating trust measures for e-commerce: An integrative typology', Information Systems Research, 13(3), 334-359.

Parasuraman, A. and Zinkhan, G.M. (2002). 'Marketing to and serving customers through the Internet: An overview and research agenda', Journal of the Academy of Marketing Science, 30(4), 286-295.

Park, C. (2002). A Model on the Online Buying Intention with Consumer Characteristics and Product Type. Department of Management Information Systems/ Korea University,_Jochiwon, Chungnam, South Korea.

Pavlou, P.A. (2003). 'Consumer acceptance of electronic commerce: integrating trust and risk with the technology acceptance model', International Journal of Electronic Commerce, 7(3), 101-134.

Piron, F. (1991). 'Defining impulse purchasing', Advances in Consumer Research 18, Rebecca Holman and Michael Solomon, eds., Provo, UT: Association for consumer research 509-514.

Rajshekhar, G.J., Radulovich, L.P., Pendleton, G. and Scherer, R.F. (2005). 'Sustainable competitive advantage of internet firms: A strategic framework and implications for global marketers', International Marketing Review, 22(6), 658-672.

Rook, D.W. (1987). 'The buying impulse', Journal of Consumer Research, 14(2), 189-1999.

Rook, D.W. and Fisher, R.J. (1995) 'Normative influence on impulse buying behavior', Journal of Consumer Research, 22, 305-313.

Salisbury, W.D., Pearson, R.A., Pearson, A.W. and Miller, D.W. (2001). 'Perceived security and worldwide web purchase intention. Industrial Management \& Data Systems, 101(4), 165-177.

Seckler, V. (2000). 'Survey says Web apparel buys doubled', Women Wear Daily, 12, July, pp.2.

Seiders, K., Berry, L.L., and Gresham, L.G. (2000). 'Attention, retailers! How convenient is your convenience strategy?', Sloan Management Review, 41(3), 79-89.

Sekaran, U. and Bougie, R. (2010). Research methods for business, $5^{\text {th }}$ edn, West Sussex: John Wiley \& Sons.

Seock, Yoo-Kyoung. (2003). Analysis of clothing websites for young customer retention based on a model of customer relationship management via the internet. Unpublished doctoral dissertation, Virginia Polytechnic Institute and State University. 
Shim, S. and Drake, M.F. (1990). 'Consumer intention to utilize electronic shopping', Journal of Direct Marketing, 4(2), 22-33.

Shim, S., Eastlick, M.A., Lotz, S.L. and Warrington, P. (2001). 'An online prepurchase intentions model: $\quad$ the role of intention to search', Journal of Retailing, 77(3), 397-416.

Shim, S. and Kotsiopulos, A. (1992). 'Patronage behavior of clothing shopping: Part I. Shopping orientations, store attributes, information sources, and personal characteristics', Clothing and Textiles Research Journal, 10(2), 48-57.

Shim, J.K., Quereshi, A. A. and Siegel, R.M. (2000). The international handbook of electronic commerce. Glenlake Publishing Company. The Emerging Digital Economy, U.S.Department of Commerce.

Solomon, M.R., Dann, S., Dann, S. and Russell-Bennett, R. (2007). Consumer behaviour: Buying, having, being, NSW: Prentice Hall.

Sproles, G.B. and Kendall, E.L. (1986). 'A methodology for profiling consumers' decision making styles', The Journal for Consumer Affairs, 20(2), 267-279.

Swaminathan, V., Lepkowska-White, E. \& Rao, B. (1999). 'Browser or buyers in cyberspace? An investigation of factors influencing electronic exchange', Journal of Computer-Mediated Communication, 5(1), 1-23.

Verhagen, T., Meents, S. and Tan, Y.H. (2006). 'Perceived risk and trust associated with purchasing at electronic marketplace', European Journal of Information Systems, 15(6), 542-555.

Verhagen, T., Tan, Y.H. and Meents, S. (2004). 'An empirical exploration of trust and risk associated with purchasing at electronic marketplaces', 17th Bled eCommerce Conference eGlobal, Bled, Slovenia, 21-23 June.

Vijayasarathy, L.R., \& Jones, J.M. (2000). 'Intentions to shop using Internet catalogues: Exploring the effect of the product types, shopping orientations, and attitudes toward computers', Electronic Market, 10(1), 29-38.

Ward, M.R. and Lee, M.T. (2000). 'Internet shopping, consumer search, and product branding', Journal of Product and Brand Management, 9(1), 6-21.

Weber, K. and Roehl, W. (1999). 'Profiling people searching for and purchasing travel products on the World Wide Web', Journal of Travel Research, 37(3), 291-298.

Weinberg, P. and Gottwald, W. (1982). 'Impulse consumer buying as a result of emotions', Journal of Business Research, 10(1), 43-48.

Wolfinbarger, M. and Gilly, M.C. (2001). 'Shopping online for freedom, control, and fun', California Management Review, 43(2), 34-55.

Wolman, B. (1973). Dictionary of behavioral science, New York: Van Nostrand Reinhold.

Wu, J.J. and Cheng, Y.S. (2005). 'Towards understanding members' interactivity, trust, and flow in online travel community', Industrial Management \& Data Systems, 105(7), 937-954.

Yousafzai, S.Y., Pallister, J.G. and Foxall, G.R. (2003). 'A proposal model of e-trust for electronic banking', Technovation, 23(1).

Zhang, X., Prybutok, V.R. and Strutton, D. (2007). 'Modeling influences on impulse purchasing behaviors during online marketing transactions', Journal of Marketing Theory and Practice, 15(1), 79-89.

Zikmund, W.G., Babin, B.J., Carr, J.C. and Griffin, M. (2010). Business research methods, $9^{\text {th }}$ edn, Canada: South-Western Cengage Learning. 
Table 1. Factors Identified by the Principal Components Factor Analysis

\begin{tabular}{|c|c|c|c|c|c|}
\hline $\begin{array}{l}\text { Factor's } \\
\text { Name }\end{array}$ & Variable & $\begin{array}{c}\text { Factor } \\
\text { Loading }\end{array}$ & Eigen-value & $\begin{array}{c}\text { Percentage } \\
\text { of Variance } \\
\text { Explained } \\
\end{array}$ & $\begin{array}{l}\text { Cronbach's } \\
\text { Reliability } \\
\text { Coefficients } \\
\end{array}$ \\
\hline $\begin{array}{l}\text { Impulse } \\
\text { Purchase } \\
\text { Orientation }\end{array}$ & $\begin{array}{l}\text { I am impulsive when purchasing } \\
\text { products/services through web-retailer. } \\
\text { When my intention is to merely browse through } \\
\text { the web site, I sometimes make a purchase. } \\
\text { When I purchase products/services } \\
\text { spontaneously from the web-retailer, I feel } \\
\text { released. } \\
\text { I plan my online purchase carefully. }\end{array}$ & $\begin{array}{l}0.729 \\
0.769 \\
0.829 \\
0.719\end{array}$ & 2.388 & 10.308 & 0.798 \\
\hline $\begin{array}{l}\text { Online } \\
\text { Purchase } \\
\text { Intention }\end{array}$ & $\begin{array}{l}\text { It is likely that I will transact with this web } \\
\text { retailer in the near future. } \\
\text { Given the chance, I intend to use this retailer's } \\
\text { web site. } \\
\text { Given the chance, I predict that I should use this } \\
\text { retailer's web site in the future. }\end{array}$ & $\begin{array}{l}0.756 \\
0.731 \\
0.714\end{array}$ & 1.064 & 8.210 & 0.867 \\
\hline $\begin{array}{l}\text { Brand } \\
\text { Orientation }\end{array}$ & $\begin{array}{l}\text { If I buy products/services from a web-retailer that } \\
\text { I am familiar with, I would prefer to buy } \\
\text { well-known brand name. } \\
\text { It is important for me to buy products/services } \\
\text { from the web-retailer with well-known brand } \\
\text { names. } \\
\text { Once I find a brand I like through web-shopping, } \\
\text { I stick with it. }\end{array}$ & $\begin{array}{l}0.869 \\
0.893 \\
0.822\end{array}$ & 1.635 & 9.728 & 0.868 \\
\hline $\begin{array}{l}\text { Quality } \\
\text { Orientation }\end{array}$ & $\begin{array}{l}\text { The availability of high-quality products/services } \\
\text { provided by the web-retailer is very important to } \\
\text { me. } \\
\text { I find better quality products/services from the } \\
\text { web-retailer. } \\
\text { My standards and expectations from the } \\
\text { products/services I buy from web-retailer are } \\
\text { very high. }\end{array}$ & $\begin{array}{l}0.832 \\
0.795 \\
0.849\end{array}$ & 1.568 & 8.695 & 0.803 \\
\hline $\begin{array}{l}\text { Prior Online } \\
\text { Purchase } \\
\text { Experience }\end{array}$ & $\begin{array}{l}\text { I am experienced with the use of the web site. } \\
\text { I feel competent of using the web site. } \\
\text { I feel comfortable of using the web site. } \\
\text { I feel that the web site is easy to use }\end{array}$ & $\begin{array}{l}0.686 \\
0.710 \\
0.777 \\
0.742\end{array}$ & 3.115 & 10.362 & 0.797 \\
\hline Online Trust & $\begin{array}{l}\text { The web site of this web-retailer is trustworthy } \\
\text { and honest. } \\
\text { The web site of this web-retailer wants to keep } \\
\text { promises and obligations. } \\
\text { The information provided by the web-retailer is } \\
\text { plentiful and of sufficient quality. } \\
\text { The infrastructure of the web site of this } \\
\text { web-retailer is dependable. } \\
\text { The web site of this web-retailer offers secure } \\
\text { personal privacy. } \\
\text { The web site of this web-retailer keeps my best } \\
\text { interests in mind. } \\
\text { Compared to other web site offered, the web site } \\
\text { of this web-retailer is secure and reliable. } \\
\text { The web site of this web-retailer would not } \\
\text { behave opportunistically (e.g., gaining money } \\
\text { illegally). } \\
\text { The performance of the web site of this } \\
\text { web-retailer fulfills my expectation. }\end{array}$ & $\begin{array}{l}0.696 \\
0.703 \\
0.737 \\
0.679 \\
0.720 \\
0.676 \\
0.718 \\
0.683 \\
0.618\end{array}$ & 7.242 & 18.131 & 0.880 \\
\hline
\end{tabular}

Note: KMO Measure of Sampling Adequacy $=0.867 ; \mathrm{p}=0.000(\mathrm{p}<0.05) ; \mathrm{df}=325$

Cumulative Percentage Rotation Sums of Squared Loadings $=65.434$ 
Table 2. Result of Multiple Linear Regression Analysis

\begin{tabular}{|c|c|c|c|c|c|c|}
\hline & & \multicolumn{2}{|c|}{ Unstandardized Coefficients } & \multirow{2}{*}{$\begin{array}{c}\begin{array}{c}\text { Standardized } \\
\text { Coefficients }\end{array} \\
\text { Beta } \\
\end{array}$} & \multirow{2}{*}{$\mathbf{T}$} & \multirow{2}{*}{ Sig. } \\
\hline & & B & Std. Error & & & \\
\hline \multirow[t]{6}{*}{1} & (Constant) & -0.546 & 0.884 & & -0.617 & 0.538 \\
\hline & $\begin{array}{l}\text { Impulse Purchase } \\
\text { Orientation }\end{array}$ & 0.170 & 0.040 & 0.216 & 4.264 & 0.000 \\
\hline & Quality Orientation & 0.100 & 0.047 & 0.106 & 2.129 & 0.034 \\
\hline & Brand Orientation & 0.130 & 0.039 & 0.166 & 3.337 & 0.001 \\
\hline & Online Trust & 0.091 & 0.020 & 0.244 & 4.639 & 0.000 \\
\hline & $\begin{array}{l}\text { Prior Online Purchase } \\
\text { Experience }\end{array}$ & 0.279 & 0.043 & 0.351 & 6.439 & 0.000 \\
\hline
\end{tabular}

a Dependent Variable: Online Purchase Intention

Independent variables: Impulse purchase orientation, quality orientation, brand orientation, online trust and prior online purchase experience

$\mathrm{R}=69.4$ per cent; $\quad \mathrm{R}$ Square $=48.2$ per cent; $\quad$ Adjusted $\mathrm{R}$ Square $=47.1$ per cent;

$\mathrm{F}=43.970 ; \mathrm{P}=0.000(\mathrm{p}<0.05)$

Table 3. Summary of the Five Hypotheses and Outcomes

\begin{tabular}{|l|l|l|}
\hline \multicolumn{1}{|c|}{ Independent variables tested } & \multicolumn{1}{|c|}{ Hypotheses } & Outcome \\
\hline Impulse Purchase Orientation & H1: Impulse purchase orientation is positively related to the customer & Supported \\
Quality orientation & online purchase intention. & Supported \\
Brand orientation & H2: Quality orientation is positively related to the customer online & Supported \\
$\begin{array}{l}\text { Online Trust } \\
\text { Prior Online Purchase }\end{array}$ & purchase intention. & Supported \\
Experience & intention. Brand orientation is positively related to the customer online purchase & \\
& $\begin{array}{l}\text { H4: Online trust is positively related to the customer online purchase } \\
\text { intention. }\end{array}$ & \\
& H5: Prior online purchase experience is positively related to the customer \\
& online purchase intention.
\end{tabular}

